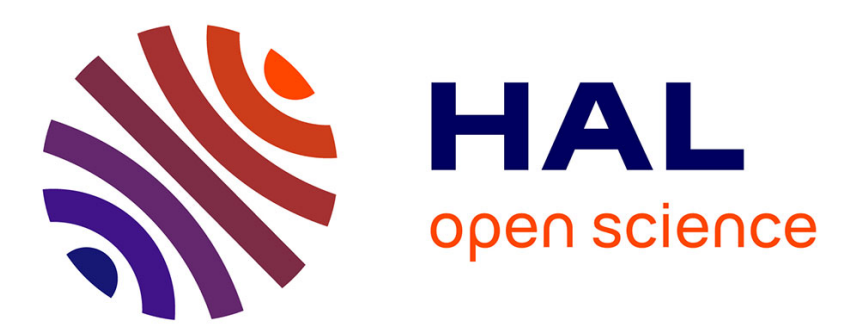

\title{
On-site identification of Sceaux porcelain and faience using a portable Raman instrument
}

\author{
D. Mancini, C. Dupont-Logié, Ph. Colomban
}

\section{To cite this version:}

D. Mancini, C. Dupont-Logié, Ph. Colomban. On-site identification of Sceaux porcelain and faience using a portable Raman instrument. Ceramics International, 2016, 42 (13), pp.14918-14927. 10.1016/j.ceramint.2016.06.132 . hal-01338375

\section{HAL Id: hal-01338375 \\ https://hal.sorbonne-universite.fr/hal-01338375}

Submitted on 28 Jun 2016

HAL is a multi-disciplinary open access archive for the deposit and dissemination of scientific research documents, whether they are published or not. The documents may come from teaching and research institutions in France or abroad, or from public or private research centers.
L'archive ouverte pluridisciplinaire HAL, est destinée au dépôt et à la diffusion de documents scientifiques de niveau recherche, publiés ou non, émanant des établissements d'enseignement et de recherche français ou étrangers, des laboratoires publics ou privés. 


\title{
On-site identification of Sceaux porcelain and faience using a portable Raman instrument
}

\author{
D. Mancini ${ }^{\mathrm{a}, \mathrm{b}}$, C. Dupont-Logiéc ${ }^{\mathrm{c}}, \mathrm{Ph}$. Colomban ${ }^{\mathrm{a}, \mathrm{b}^{*}}$
}

a Sorbonne Universités, UPMC Univ Paris 06, UMR 8233, MONARIS, 75005 Paris, France ${ }^{\mathrm{b}}$ CNRS-IP2CT, UMR 8233, MONARIS, 75005 Paris, France

${ }^{c}$ Département du Patrimoine et des Collections de la Cité de la Céramique, 92310 Sèvres, France

corresponding author. Tel: +33144272785; fax: +33144273021. philippe.colomban@ upmc.fr

\begin{abstract}
During the $18^{\text {th }}$ century many European manufactures tried to imitate Chinese, Vietnamese and Japanese porcelain. To address the lack of kaolin source they had to test new processes inspired from the fritware technology. Unfortunately, the Sceaux Factory production is poor documented: it was only vaguely reported that different technologies were used to produce soft-paste and hard-paste porcelain as well as different kinds of faiences, including an undocumented "faïence japonnée”. In order to bring new information, a selection of 25 objects from the Département du Patrimoine et des Collections de la Cité de la Céramique, Sèvres, France, attributed to the $18^{\text {th }}$ century Sceaux Factory production, has been analyzed with a portable 532nm Raman spectrometer in museum reserves. Identification of the crystalline phases of the body and glaze as well as pigments allows differentiating the different technologies. According to previous studies on porcelains produced by other factories in Paris area (Chantilly, Saint-Cloud, Mennecy, Vincennes/Sèvres, etc.), wollastonite $\left(\beta \mathrm{CaSiO}_{4}\right)$ appears to be characteristic of soft-paste porcelain paste. Therefore, the absence of wollastonite peaks is consistent with a faience body and the concomitance with the presence of quartz peaks can correspond either to hard-paste porcelain or to faience. Cassiterite, wollastonite and quartz are identified as glaze opacifiers. Different olivine and pyrochlore compositions have been evidenced for blue and yellow pigments, respectively. This fact can be related to different pigment technologies (periods or Master).
\end{abstract}


Keywords: pottery, porcelain, soft-paste, hard-paste, Sceaux, Raman

\section{INTRODUCTION}

Chinese, Vietnamese and Japanese porcelains imported by Portuguese and then VOC traders during the $16^{\text {th }}$ and $17^{\text {th }}$ centuries were highly appreciated by European Courts [1]. With the exception of Medici hybrid porcelain produced during a few years in Florence (1575-1587) [2] attempts to produce similar objects in Europe did not succeed before the end of the $17^{\text {th }}$ century (Rouen: >1673 and Saint-Cloud >1695)[3,4]. Actually two routes were experimented: the soft-paste technique issued from the fritware technology (rather similar to ancient Egyptian "faience" and Ottoman Iznik/Kütahya productions)[5-7] and the hard-paste technique [7] similar to that of China ware. China wares require to be prepared by sinteringreaction a mixture of kaolin (a hydroxylated aluminosilicate similar to clays), pegmatite (mainly K- and Na-based feldspars) and sand (silica) [7-9]. Firing led to the formation of a Krich liquid phase that dissolved other phases and promoted, above $1250^{\circ} \mathrm{C}$, the formation of mullite needles. Needles formed a bird nest mesh retaining the liquid phase and preventing the deformation of the object shape [10]. The final alumina-rich material (typical composition: $\mathrm{K}_{2} \mathrm{O} 4 \mathrm{wt} \%, \mathrm{Al}_{2} \mathrm{O}_{3} 26 \mathrm{wt} \%$ and $\left.\mathrm{SiO}_{2} 70 \mathrm{wt} \%\right)$ consists in mullite needles ( $16-20 \%$ in volume) in a glassy matrix plus some relics of poor dissolved raw materials ( $\sim 20 \%$ vol. quartz and feldspar). Glazed artefact can be obtained in a single firing cycle. On the contrary, the soft-paste body is silica-rich $\left(\mathrm{K}_{2} \mathrm{O} 4 \mathrm{wt} \%, \mathrm{Na}_{2} \mathrm{O} 1.7 \mathrm{wt} \%, \mathrm{CaO} 16 \mathrm{wt} \%, \mathrm{Al}_{2} \mathrm{O}_{3} 2.5 \mathrm{wt} \%\right.$ and $\mathrm{SiO}_{2} 75 \mathrm{wt} \%$ ) [7]. Following the antique fritware technique, sand grains were cemented together by addition of a small amount of clay/marl, carbonates (and glue) and glass (the frit). On heating the glass melts, reacts with and welds the quartz grains. The firing temperature required to sinter soft-paste porcelain is 200 to $400^{\circ} \mathrm{C}$ lower than that required to prepare hard-paste porcelain $\left(1200\right.$ to $1450^{\circ} \mathrm{C}$, typically) [11,12]. The low sintering temperature of soft-paste porcelain imposed the choice of lead-based glazes, easily scratched by a knife, a characteristic at the origin of the name. Two firings are made, the first for the body and the 


\section{ACCEPTED MANUSCRIPT}

second for the glaze and its décor. Furthermore evolution of the mixture viscosity with temperature is very different: for hard-paste porcelain the viscosity decrease is slow, what permits a large temperature window (also optimized by the temperature dwell duration); on the contrary the window is very small for fritware: a few tens of degrees are sufficient to go from an unfired object to a flake! Wollastonite $\beta\left(\mathrm{CaSiO}_{4}\right)$ forms on cooling lime-saturated silicate melt.

The lack of kaolin sources limited the attempts to produce hard-paste wares in Europe. E. W. von Tschirnhaus and J.F. Böttger were the first to search and identify kaolin in Saxony and to achieve in 1710 the production of red than white hard-paste stoneware and porcelain $[13,14]$. The know-how spread to Vienna (1718), Strasburg (1751) and then in many towns [7]. Production of soft-paste wares was concomitant, namely in Saint-Cloud (1695), Chantilly (1725), Vincennes/Sèvres (1740/1756) and Mennecy (1748) [7]. Actually porcelain production in France was a King Family' privilege that strongly limited the number of factories.

François Bardin, an ancient arcanist from the Saint-Cloud Manufacture founded a factory in Paris, rue de Charonne in 1720 and then moved in 1735 to Villeroy Castle, south of Paris, belonging to the Duke L F.A. de Neufville. In 1748 he displaced the factory to the neighbour village, Mennecy (objects are signed D.V.). He died in 1765 and his widow associated the factory to that of J. Julien and S. Jacques at Sceaux, then moved at Bourg-laReine, in 1772 under the protection of L.C. de Bourbon (objects are signed B.R.). Simultaneously, L.F. de Bey founded a porcelain factory in Sceaux (joint village of Bourg-laReine) in 1735 under the protection of Main Duchesse. In 1748 Jacques Chapelle, after having worked in Vincennes and Strasburg jointed him (objects are signed J.C.). Immediately, a decision from the King Council imposed to stop the production because of the Vincennes Royal Factory Porcelain Privilege. Chapelle and Bey claimed not to produce porcelain but some "Faience japonnée", a new and unknown type of pottery. Actually they produced different pastes, faiences and porcelains, and in 1753 finally obtained the permission to make porcelain. From 1763 to 1772 the Sceaux Factory belonged to J. Julien and S. Jacques, owners of the Mennecy Factory. In 1772 Richard Glot bought the factory (mark: SX or SP, with anchor) and continued the production up to 1794 [15-18]. The very complex history of Sceaux 


\section{ACCEPTED MANUSCRIPT}

productions requires objective clarification tools to support assignments based on stylistic criteria, many items being free of marks.

Raman (micro)spectroscopy allows efficient identification of amorphous and crystalline phases made of covalent bonds [19-21]. Fifteen years ago [22,23] we demonstrated the potential of Raman scattering to document the technology of production of ancient ceramic objects, in particular to discriminate between alumina-rich hard-paste and silica-rich soft-paste porcelain. We demonstrated also that the glaze composition type and pigments can be recognized from the Raman spectra [24]. We were also the first to conduct on-site analysis of ancient pottery and glass [5,6, 25-29]. We present here a comprehensive on site study of artefacts from the Collection of Sèvres Cité de la Céramique assigned to the Sceaux Factory. Many of these artefacts entered in the Collection at the beginning of the $19^{\text {th }}$ century [30]. Comparison will be made with previous measurements performed at the Laboratory with bench-top instruments in 2004 for well referenced objects from Saint-Cloud, Chantilly, Vincennes, Sèvres and Mennecy Factories. Additionally, faience, soft-paste porcelain and intermediate type shards excavated from the ancient Chantilly production site will be considered for comparison.

\section{EXPERIMENTAL METHODS AND OBJECTS}

Fig. 1 shows the portable set-up used to analyse the artefacts in the Cite de la Céramique Reserves. A Nd:YAG Laser (Quantum Ventus 100 or 300 mW, UK) emitting at $532 \mathrm{~nm}$ injects the beam in an optical fibre up to a remote SuperHead® (Jobin-Yvon Horiba, France). The optical head is equipped with a long working distance microscope objectives (50x Nikon, 50x and 200x Mititoyo, Japan). The same optics is used to focus the beam on the artefact and to collect the scattered light. The laser light is edge filtered and sent through a second optic fibre to the HE532 Spectrometer (Jobin-Yvon Horiba) equipped with a Peltier cooled CCD. The quality of the focus is optimised at very low laser power by eyes examination. A rather heavy $(8 \mathrm{~kg})$ micrometric XYZ stage supports the remote head and permits to move it at the micron scale. The weight of the stage guaranties the absence of vibrations during the measurement. Furthermore, the object to analyse and the XYZ stage are put on paper sheets to avoid any vibrations. We first adjust the focus point with eyes examination at very low laser power in the dark. A black textile is then put on the object and 


\section{ACCEPTED MANUSCRIPT}

head in order to protect them from the ambiance light and the operator from the laser light. Working in dark is welcome. The laser power is increased to have between $\sim 10-20 \mathrm{~mW}$ (body and white glaze analysis) and 1-4 $\mathrm{mW}$ (coloured glaze). The maximum of the background (fluorescence) intensity indicates that the focus is close to the best. The final focus is adjusted following the quality of the Raman signature. Micronic displacement of the focus through the glaze from the top surface to the body allows measuring the glaze thickness and analysing underglaze décor and glaze-body interphase. Spectral resolution is $\sim 5 \mathrm{~cm}^{-1}$. Baseline subtraction can be made according a procedure established previously in order to highlight the low intensity Raman peaks [31].

Figs 2 to 4 show the studied artefacts. Spots analyzed are shown in Supplementary materials (Figs S1 to S6). Information is summarized in Tables 1 and 2. A first group presented in Fig. 2 consists in three plates, a dish, a stopper and a ewer all assigned as "faience" and a clock support, marked J. Chapelle on the back, assigned as a soft-past porcelain The shape of the object copies that of similar metal artefact. Figs 3 and 4 shows artefacts assigned to be made of soft-paste porcelain. Many décors are made inspired from Meissen productions. Special attention should be paid to the high quality enamelled biscuit such as item MNC26234.

Porcelain and faience shards recovered during building works performed where the ancient Chantilly Factory was originally located, sliced with a diamond saw (Minitom Struers, Danemark) in order to get a good section were used for comparison.

\section{RESULTS AND DISCUSSION}

Figs 5 and 6 show characteristic spectra. Even in the case of low fluorescence contribution, because of the edge filter and the optic fibres, the background increases linearly from $\sim 100$ to $\sim 450 \mathrm{~cm}^{-1}$ and then remains almost constant [31]. Small waves are observed when the Raman signal is very weak due to the multilayer structure of the dielectric notch filter. The Raman signal being proportional to the polarizability of the chemical bonds involved, a strong signal is observed only for lead-based glazes (e.g. \#19184 and 25991) and for lead-based pigments (yellow (and green) pigments).

\section{Body analysis}


Phases identified in body are listed in Table 3. Artefacts are listed as a function of their expected production date listed in Sèvres Museum records considering stylistic criteria and marks. We will first consider the artefacts identified as tin oxide glazed faience and faience fine in Sèvres Museum catalogues (Table 1).

The impossibility to obtain a spectrum exhibiting narrow peak(s) is consistent with the fact that the object is faience. However the very porous character of the faience body (typically 15 to $25 \%$ [32]) hinders the formation and collection of the Raman scattering. Furthermore, a biologic film is generally present at the pore surface of ancient pottery, which promotes fluorescence. For instance items \#5778.2, 19184, 23422 and 76486 don't exhibit spectra. We can conclude doubtless that their body is not a soft-paste. Two of them, items \#23422 and 76486, were assigned as Sceaux and probably Sceaux soft-paste porcelain in Sèvres catalogue (Table 2). The assignment is wrong. Note that all the artefacts exhibiting a Raman signature consistent with that expected for faience have been produced during the first years, according the historical records above mentioned.

Peaks of $\beta$ wollastonite at $\sim 972$ (vs $\mathrm{SiO}_{4}$ ), 635 ( $\delta$ as $\mathrm{SiO}_{4}$ ), 998-1022-1046 (vas $\mathrm{SiO}_{4}$ ), $416\left(\mathrm{Ss} \mathrm{SiO}_{4}\right)$ and $347\left(\mathrm{R}^{\prime} \mathrm{SiO}_{4}\right)$ are characteristic of soft-paste porcelain [7]. Traces of wollastonite are observed for the items \#25991 stopper and \#5497 Mustard pot, what questions their assignment as faience fine (Table 1, see further discussion). Quartz signature is also observed for the first artefact. Quartz is commonly the only observed peak on hard-paste porcelain [7] because un-dissolved quartz grains remain present in the body. Contamination of the un-glazed part with glaze during the fabrication is also possible. The best criterion to discriminate between faience and porcelain is the clear ton obtained on porcelain (open porosity $<2 \%$ ).

All items presented in Figs 3 and 4 exhibiting a strong wollastonite Raman fingerprint are doubtless soft-paste porcelain. Finally, two items \# 10053 and 13713 don't exhibit wollastonite peaks and could be made of hard paste porcelain (see further). Items \#9096 and 25991 where wollastonite traces are weak could be a material intermediate between faience and soft paste, in other words an incompletely fired soft-paste. Intensity of the Raman signature of quartz is absent or very small/rare for soft-paste body [3]. Cristobalite was not 


\section{ACCEPTED MANUSCRIPT}

evidenced, contrarily to Chantilly Factory productions [3]. The two plates items \#4162 and 19674 assigned as faience in Sèvres catalogue (Table 1) exhibit wollastonite spectra characteristics of a soft-paste body.

Because of the lack of Raman data regarding faience body from the $18^{\text {th }}$ century, we analyzed Chantilly shards rather similar to Sceaux faience. Fig S7 compares typical sections of a soft-paste and a fine faience excavated from the Chantilly Factory. The soft-paste body is rather dense; the mean grain size is $\sim 15 \mu \mathrm{m}$ and the mean pore diameter $\sim 30 \mu \mathrm{m}$. The pore size of faience is larger $(\sim 100 \mu \mathrm{m})$ but the grain size smaller. Collection of Raman spectra in many points of the shard section with 50x objective (analyzed surface $\sim 25 \mu \mathrm{m}^{2}$ ) confirms that the phase observed for Chantilly soft-paste is wollastonite $\beta$. For faience shard we only observed in some spots the signature of quartz and in rare cases the spectrum of rutile could be detected. Note that the huge intensity of the later phase makes easy the detection of traces. This confirms that the absence of wollastonite and quartz signature is consistent with a faience body.

\section{Glaze and colouring agents}

Most of the glazes exhibit the signature of $\beta$ wollastonite (Table 3). Some glazes are opacified with cassiterite. This is the case for three faience (items \# 5778.2, 19184 and 20505b) as expected by Curators, five soft-pastes (items \#22748, 23257, 23258, and 4162) and one hard-paste (\#10053). The three faience $(5778,20505 \mathrm{~b}$ and 19184) and three porcelains $(23257,13713$ and 14156) glazes don't show wollastonite peaks.

Two different signatures are observed for blue décors: i) nothing according to the presence of $\mathrm{Co}^{2+}$ ions dissolved in the glaze [24,34,35] (faience 23422, soft-paste 5497 and soft-paste 4162), ii) a strong peak at around $820 \mathrm{~cm}^{-1}$, as expected for the olivine $\mathrm{CoSiO}_{4}$ structure [24]. Actually the shift of the peak position from 812 to $830 \mathrm{~cm}^{-1}$ and the different intensities indicates different compositions or structural distortions resulting from different preparation/origin of the cobalt raw material (Fig. 6). Similar variable signatures are observed for some green décor (\#25991 faience, 21622 soft-paste and 23422 soft-paste), the green colour being obtained by dispersing yellow pigment and blue glass/pigment [24,34]. Two different yellow pigments are also identified. Their Raman spectra show characteristic modes of $\mathrm{Pb}_{2} \mathrm{M}_{2-\mathrm{x}} \mathrm{M}_{\mathrm{x}} \mathrm{O}_{7-\delta}$ pyrochlore, the so called Naples Yellow pigment: a strong $\mathrm{Pb}-\mathrm{O}$ mode 


\section{ACCEPTED MANUSCRIPT}

peaking at 124 to $137 \mathrm{~cm}^{-1}$ and a Sb-O mode at $\sim 508 \mathrm{~cm}^{-1}$ [35-43]. The shift of the first peak to higher values is correlated to the intensity increase of the 330 and $450 \mathrm{~cm}^{-1}$ modes, according to the partial substitution of Sb atom by $\mathrm{Sn}, \mathrm{Zn}, \mathrm{Si}$ etc. atoms [35-43]. No correlation is found with the nature of the body, the different glaze composition should be chosen to control the hue. The wavenumber shift and relative intensity don't only depend on the composition but also from the firing temperature and atmosphere.

Classically red and orange colours are obtained with hematite (see intense signal in \#4162, 20505b, 23422 and 14156 with 217, 286, 400, 499, 600 and $~ 1300 \mathrm{~cm}^{-1}$ peaks).

Wavenumber maxima of the $\mathrm{SiO}_{4}$ bending vs. stretching massifs allow discriminating between the different compositions of the glaze [44]. However the complex shape of the background for portable instruments makes often the determination of the bending band maximum inaccurate. However some pieces of information can be extracted from the stretching mode. Almost all glazes exhibit peaks between 1000 and $1010 \mathrm{~cm}^{-1}$ a lower value than observed for hard-paste glaze, because of the lower firing temperature [45]. This indicates that the glass is partially depolymerised, according to the addition of lead to allow a firing at $\sim 1000^{\circ} \mathrm{C}$ or less (Petit Feu). Lower stretching maxima are measured for yellow glaze, up to 975 (19674) 940 (20505b) or even 910 (14156) $\mathrm{cm}^{-1}$ because of the lead addition associated to the yellow pigment.

\section{CONCLUSIONS}

Despite the complex background and the medium resolution of portable instruments, the on-site non-invasive analysis of artefacts led important results. Body analysis of some artefacts assigned as faience exhibits the wollastonite $\beta$ spectrum, a phase typical of soft-paste porcelain according to previous studies on porcelains produced by other Factories in Paris area (Chantilly, Saint-Cloud, Mennecy, Vincennes/Sèvres, etc.). Incomplete firing of a soft paste could maintain a level of porosity sufficiently high to make the manual acoustic test close to that expected for faience and led to a wrong assignment. Analysis of the sample microstructure (i.e. sampling for thermal expansion and composition measurements) is needed 


\section{ACCEPTED MANUSCRIPT}

to go deeper in the discussion, especially to collect arguments to establish if the incompletely firing was intentionally or not. In this way, “faience japonnée’ would be a soft-paste porcelain, intentionally incompletely fired in order to respect the King' privilege. The absence of wollastonite peaks and the presence of a quartz peak can correspond either to hard-paste porcelain or to faience; the differentiation can be made from the sound and the mass of the object. The mullite signature, characteristic of hard-paste porcelain is hardly detected because its intensity is always very low. An advanced laboratory instrument and a rather high laser power focused on the pottery section or microfracture are needed. Glaze Raman signatures are typical of lead-glaze composition. Cassiterite, wollastonite and quartz are identified as glaze opacifiers. Different olivine and pyrochlore compositions have been evidenced for blue and yellow pigments, respectively.

References

1. M. Pirazzoli t'Serstevens, La céramique chinoise en Italie, XIIIe - début XVIe siècles, in China-Mediterranen Sea, Routes and Exchange of Ceramics prior to 16th century, Taoci (Bulletin de la Société Française d'Etude de la Céramique Orientale -Editions Findakly), 4 (2005), xx

2. Ph. Colomban, V. Milande, H. Lucas, On-site Raman Analysis of Medici Porcelain, J. Raman Spectrosc. 35[1] (2004) 68-72.

3. Ph. Colomban, I. Robert, C. Roche, G. Sagon, V. Milande, Identification des porcelaines «tendres » du 18e siècle par spectroscopie Raman: Saint-Cloud, Chantilly, Mennecy et Vincennes/Sèvres, Revue d'Archéométrie, 28 (2004) 153-167.

4. Ph. Colomban, Case study: Glasses, glazes and ceramics - Recognition of ancient technology from the Raman spectra, Edwards, HGM; Chalmers, JM Eds, Meeting on Raman Spectroscopy in Art and Archaeology Location: British Museum, London, Nov, 2001, Raman Spectroscopy in Archaeology and Art History Book Series: RSC Analytical Spectroscopy Monographs, 192-206 (2005).

5. Ph. Colomban, V. Milande, L. Le Bihan, On-site Raman Analysis of Iznik pottery glazes and pigments, J. Raman Spectrosc. 35 (2004) 527-535.

6. Ph. Colomban, R. de Laveaucoupet, V. Miland, On Site Raman Analysis of Kütahya fritwares, J. Raman Spectroscopy 36[9] (2005) 857-863.

7. Ph. Colomban, F. Treppoz, Identification and Differentiation of Ancient and Modern European Porcelains by Raman Macro- and Microspectroscopy, J. Raman Spectrosc. 32 (2001) 93-102. 


\section{ACCEPTED MANUSCRIPT}

8. W.M. Carty, U. Senapatti, Porcelain - Raw materials, processing, phase evolution, and mechanical behavior, J. Am. Cer. Soc. 81 (1998) 3-20.

9. Y. Iqbal, W.E. Lee, Microstructural evolution in triaxial porcelain, J. Am. Cer. Soc. 83 (2000) 3121-3127.

10. Ph. Sciau, L. Noé, Ph. Colomban, Metal nanoparticles in contemporary potters' master pieces: Lustre and red "pigeon blood" potteries as models to understand the ancient pottery, Ceramics Int.

11. W.D. Kingery (Ed.), Ancient Technology to Modern Science, Ceramic and Civilization Vol. I (1984). Ibidem "High Technology Ceramics - Past, Present and Future. The Nature of Innovation and Change in Ceramic Technology"; Vol. III in Ceramic and civilization; Edited by W. D. Kingery and E. Lense. Columbus, The American Ceramic Society Press (1986).

12. A. d'Albis, Traité de la Porcelaine de Sèvres, Editions Faton, Dijon, 2003.

13. W. Goder, W. Schulle, O. Wagenbreth and H. Walter, La découverte de la porcelaine européenne en Saxe Böttger, J. F. Pygmalion-Gérard Watelet Press, (1984).

14. G. Simsek, Ph. Colomban, F. Casadio,' L. Bellot-Gurlet, K. Faber, G. Zelleke, V. Milande, L. Tilliard, On-site identification of earliy Böttger red stonewares using portable XRF/Raman instruments: 2, glaze and guilding analysis, J. Am. Cer. Soc. 98[10] (2015) 3006-3013.

15. M. Brunet, A. Faÿ-Hallé, D. Lion-Goldschmidt, M. Paul-David, T. Préaud, Porcelaine, Encyclopadia Universalis [on line], 03/02/2016. URL : http://www.universalis.fr/encyclopedie/porcelaine

16. A. Faÿ-Hallé, C. Lahaussois, La Porcelaine Française au XVIIIe siècle, Histoire, motifs et marques, Les Essentiels du Patrimoine, Massin, Paris, 2011.

17. C. Maire, Histoire de la faïence fine française 1743-1843, Editions de la ReinetteRMN, Paris, 2008.

18. G. Simsek, Ph. Colomban, V. Milande, Tentative differentiation between Iznik tiles and copies with Raman spectroscopy using both laboratory and portable instrument, J. Raman Spectrosc. 41[5] (2010) 529-536.

19. Ph. Colomban, Pottery, Glass and Enamelled Artefacts: How to Extract Information on their Manufacture Technology, Origin and Age? Chapter 8, pp 245-267, in Analytical Archaeometry, H. Howell \& P. Vandenabeele Eds, Royal Society of Chemistry, Cambridge, 2012.

20. Ph. Colomban, Non-destructive Raman analysis of ancient glasses and glazes, ch. 4.2, in Modern Methods for Analysing Archaeological and Historical Glass, First Edition, K. Janssens Ed, John Wiley \& Sons Ltd, London (2012) p 275-300.

21. P. Ricciardi, Ph. Colomban, Raman spectroscopy of ceramic and glass, in IR \& Raman spectroscopy in Forensic Sciences, J.M. Chalmers, H.G.M. Edwards, M. Hargreaves Eds, Wiley \& Sons Ltd, London (2012) pp 469-479.

22. N. Q. Liem, G. Sagon, V. X. Quang, H. V. Tan, Ph. Colomban, Raman Study of the Microstructure, Composition and Processing of Ancient Vietnamese (Proto)porcelains and Celadons (13-16 ${ }^{\text {th }}$ centuries), J. Raman Spectr. 31 (2000) 933-942

23. N.Q. Liem, N.T. Thanh, Ph. Colomban, Reliability of Raman Microspectrometry in Analysis of Ancient Ceramics: The case of Ancient Vietnamese Porcelains and Celadon Glazes, J. Raman Spectr. 33[4] (2002) 287-294 


\section{ACCEPTED MANUSCRIPT}

24. Ph. Colomban, G. Sagon, X. Faurel, Differentiation of Antique Ceramics from the Raman Spectra of their Colored Glazes and Paintings, J. Raman Spectr. 32[5] (2001) 351-360.

25. Ph. Colomban, V. Milande, On Site Analysis of the earliest known Meissen Porcelain and Stoneware, J. Raman Spectrosc. 37[5] (2006) 606-613.

26. Ph. Colomban, A. Tournié, On-site Raman Identification and Dating of Ancient/Modern Stained Glasses at the Sainte-Chapelle, Paris, J. Cultural Heritage 8[3] (2007) 242-256

27. Ph. Colomban, A. Tournié, M.-C. Caggiani, C. Paris, Pigments and enamelling/gilding technology of Mamluk mosque lamps and bottle, J. Raman Spectrosc. 43 [12] (2012) 1975-1984.

28. P. Ricciardi, Ph. Colomban, A. Tournié, V. Milande, Non-destructive on-site identification of ancient glasses: genuine artefacts, embellished pieces or forgeries?, J. Raman Spectrosc. 40 (2009) 604-617.

29. P. Ricciardi, Ph. Colomban, V. Milande, Non-destructive Raman characterization of Capodimonte and Buen Retiro porcelain, J. Raman Spectrosc. 39 (2008) 1113-1119.

30. Catalogue, Département des Collections de la Cité de la Céramique.

31. $\mathrm{Ph}$. Colomban, On-site Raman identification and dating of ancient glasses: procedures and tools, J. Cultural Heritage 9 (2008) e55-e60.

32. P. Munier, Technologie des faïences, Gauthiers-Villars, Paris, 1957.

33. D. de Waal, D. Kock, Raman analysis of underglaze pigments on porcelain art, J. Raman Spectrosc. 38[7], 2007956-957.

34. Ph. Colomban, A. Tournié, M.-C. Caggiani, C. Paris, Pigments and enamelling/gilding technology of Mamluk mosque lamps and bottle, J. Raman Spectrosc. 43 [12] (2012) 1975-1984.

35. L.F. Vieira Ferreira, T. M. Casimiro, Ph. Colomban, Portuguese tin-glazed earthenware from the 17th century: pigments and glazes characterization, Spectrochimica Acta Part A 104 (2013) 437-444.

36. B. Kirmizi, H. Gokturc, Ph. Colomban, Colouring Agents in the Pottery Glazes of Western Anatolia: A New Evidence for the Use of Naples Yellow Pigment Variations during the Late Byzantine Period, Archaeometry 57 [3] (2015) 476-496.

37. Molera, J., Vendrell-Saz, M., Garcia-Valles, M., Pradell, T., 1997. Technology and colour development of Hispano-Moresque lead-glazed pottery. Archaeometry 39(1), 23-39.

38. Padeletti, G., Fermo, P., Gilardoni, S., Galli, A., 2004. Technological study of ancient ceramics produced in Casteldurante (central Italy) during the Renaissance. Appl. Phys. A. 79(2), 335-339

39. Rosi, F., Manuali, V., Grygar, T., Bezdicka, P., Brunetti, B.G., Sgamellotti, A., Burgio, L., Seccaroni, C., Miliani, C., 2011. Raman scattering features of lead pyroantimonate compounds.implication for the non-invasive identification of yellow pigments on ancient ceramics. Part II. In situ characterization of Renaissance plates by portable micro-Raman and XRF studies. J. Raman Spectrosc. 42(3), 407-414.

40. Rosi, F., Manuali, V., Miliani, C., Brunetti, B.G., Sgamellotti, A., Grygar, T., Hradil, D., 2009. Raman scattering features of lead pyroantimonate compounds. Part I: XRD and Raman characterization of $\mathrm{Pb}_{2} \mathrm{Sb}_{2} \mathrm{O}_{7}$ doped with tin and zinc. J. Raman Spectrosc. 40(1), 107-111. 


\section{ACCEPTED MANUSCRIPT}

41. Ruiz-Moreno, S., Pérez-Pueyo, R., Gabaldon, A., Soneira, M-J., Sandalinas, C., 2003. Raman laser fibre optic strategy for non-destructive pigment analysis. Identification of a new yellow pigment $(\mathrm{Pb}, \mathrm{Sn}, \mathrm{Sb})$ from the Italian XVII century painting. J. Cult. Herit. 4, 309s-313s.

42. Sakellariou, K., Miliani, C., Morresi, A., Ombelli, M., 2004. Spectroscopic investigation of yellow majolica glazes. J. Raman Spectrosc. 35(1), 61-67.

43. Sandalinas, C., Ruiz-Moreno, S., Lopez-Gil, A., Miralles, J., 2006. Experimental confirmation by Raman spectroscopy of a $\mathrm{Pb}-\mathrm{Sn}$-Sb triple oxide yellow pigment in sixteenth century Italian pottery. J. Raman Spectrosc 37(10), 1146-1153.

44. Ph. Colomban, Polymerisation Degree and Raman Identification of Ancient Glasses used for Jewellery, Ceramics Enamels and Mosaics, J. Non-Crystalline Solids 323[13] (2003) 180-187.

45. Ph. Colomban, A. Tournié, L. Bellot-Gurlet, Raman Identification of glassy silicates used in ceramic, glass and jewellry: a tentative differentiation guide, J. Raman Spectrosc. 37 [8] (2006) 841-852.

46. Vandenabeele, P.; De Paepe, P.; Moens, L., Study of the 19th century porcelain cards with direct Raman analysis, J. Raman Spectrosc. 39[8], 2008, 1099-1103.

47. Caggiani, M. C. Valotteau, C. Colomban, Ph. Inside the glassmaker technology: search of Raman criteria to discriminate between Emile Galle and Philippe-Joseph Brocard enamels and pigment signatures, J. Raman Spectrosc. 45[6], 2014, 456-464.

\section{FIGURE CAPTIONS}

Fig. 1: Set up used for on-site analysis. The black textile is put on the object and remote head when the laser power is increased. An example of collected spectrum is shown: the two narrow peaks are the signature of $\beta$ wollastonite.

Fig. 2: Sceaux pottery assigned as Faience except the clock support marked J. Chapelle on the back (see Table 1).

Fig. 3 : Sceaux pottery assigned as porcelain (see Table 2), except 16486 artefact assigned to Chantilly or Vincennes Factory, 8789 figurine to Mennecy, 9120 soupier potentially to Paris and 14156 to Vinovo (close to Turin, Italy) production.

Fig. 4: Sceaux pottery assigned as porcelain (see Table 2), except 10053 figurine assigned to Mennecy.

Fig. 5: Representative Raman spectra collected on body, white and coloured glaze. Top spectra are shown as collected. A baseline subtraction has been made for other spectra. 
Fig. 6: Representative Raman spectra collected on body, white and coloured glaze. Top spectra are shown as collected.

Fig. 7: Representative Raman recorded for blue and yellow décor.
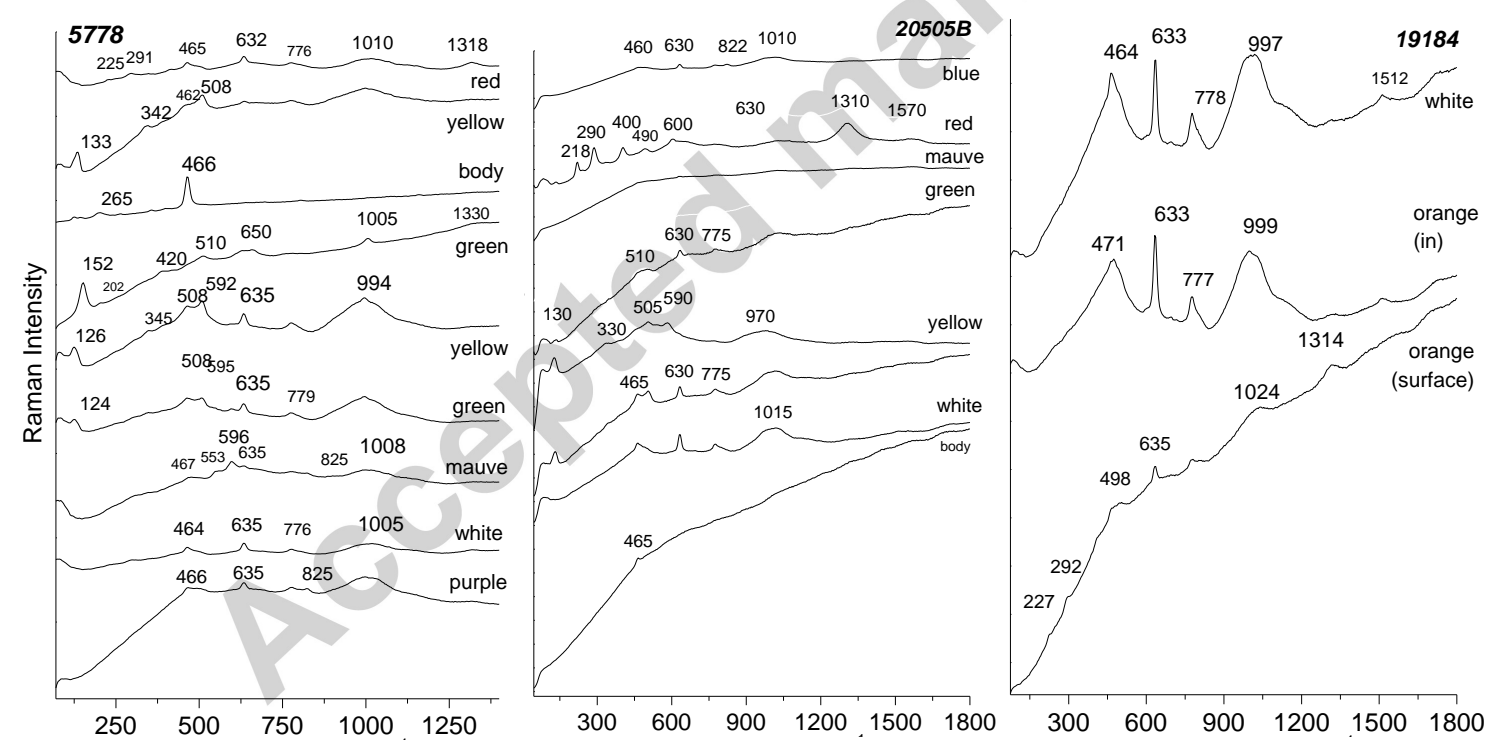

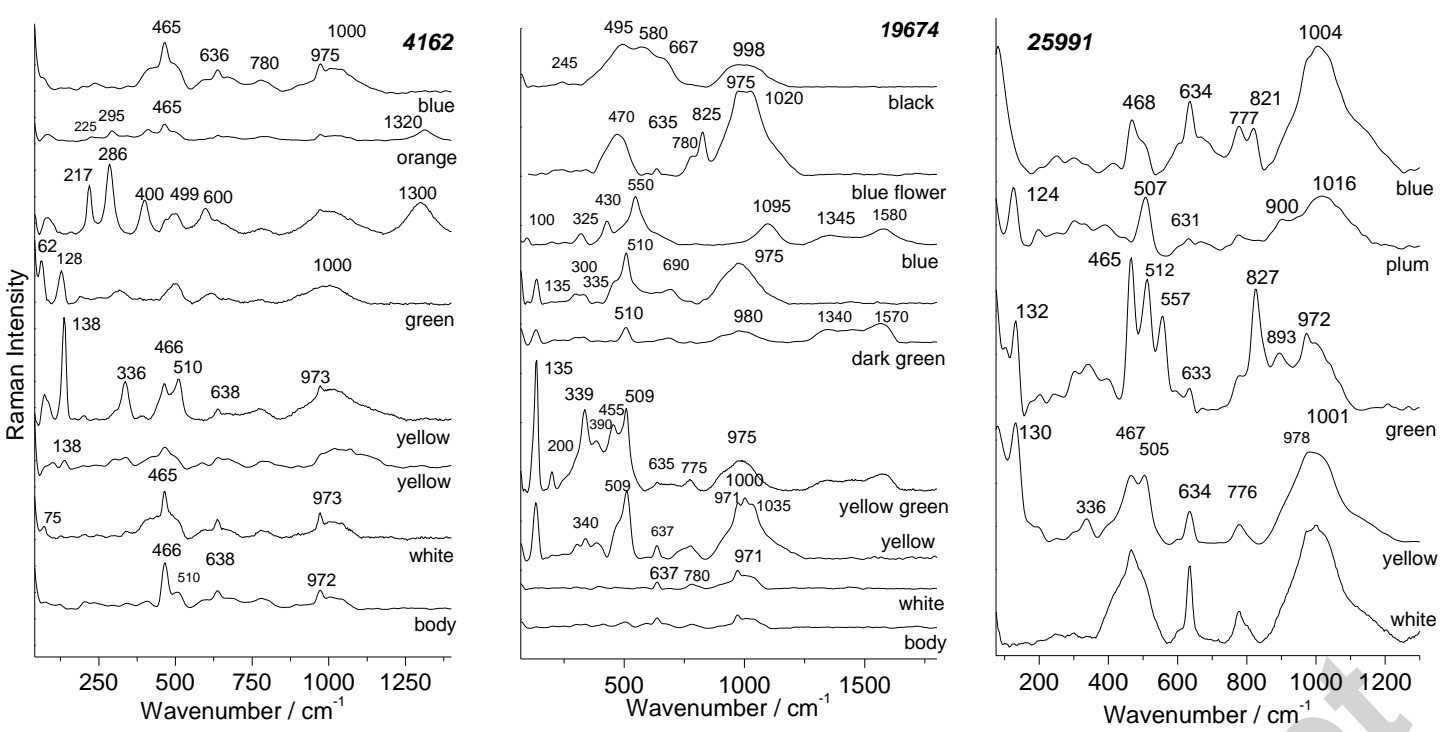

Fig. 5: Representative Raman spectra collected on body, white and coloured glaze. Top spectra are shown as collected. A baseline subtraction has been made for other spectra
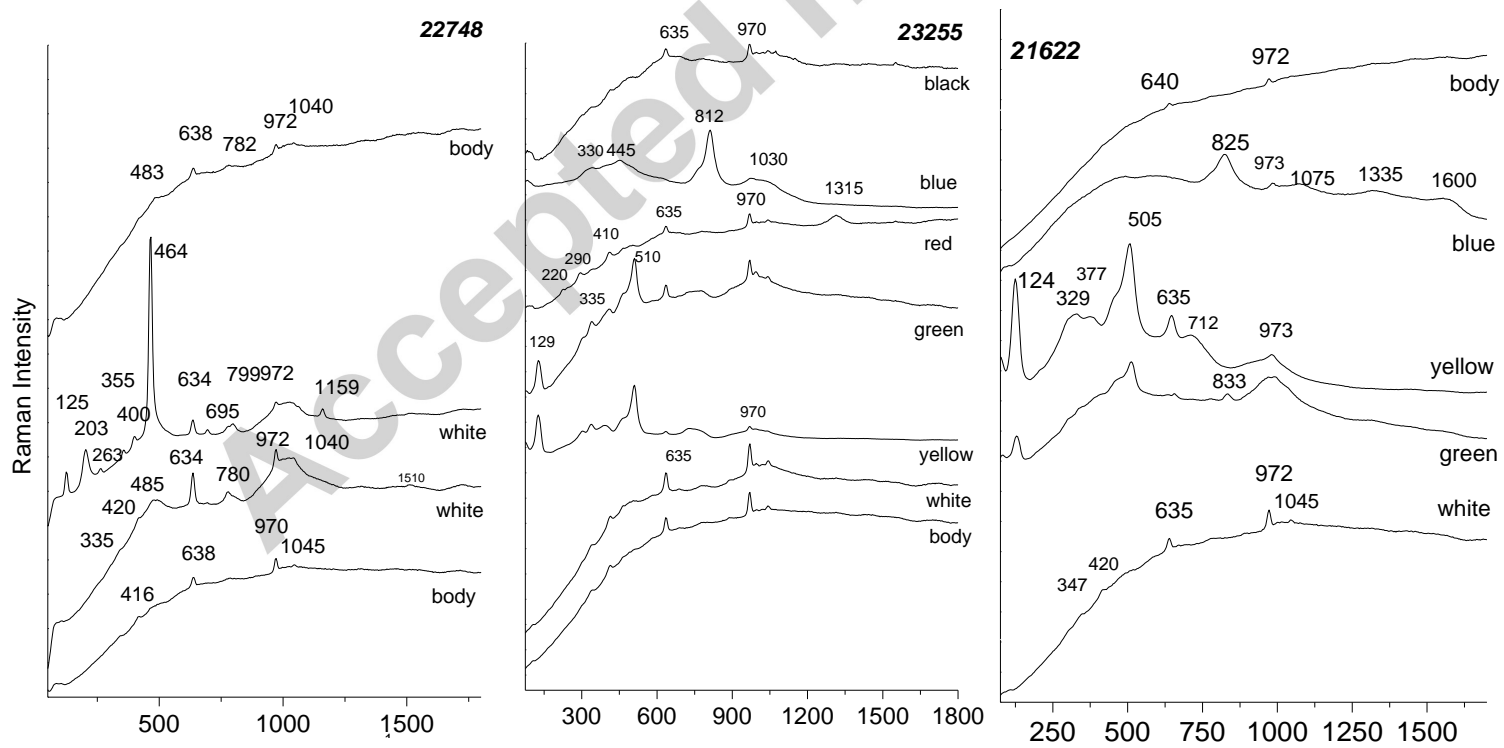


\section{ACCEPTED MANUSCRIPT}
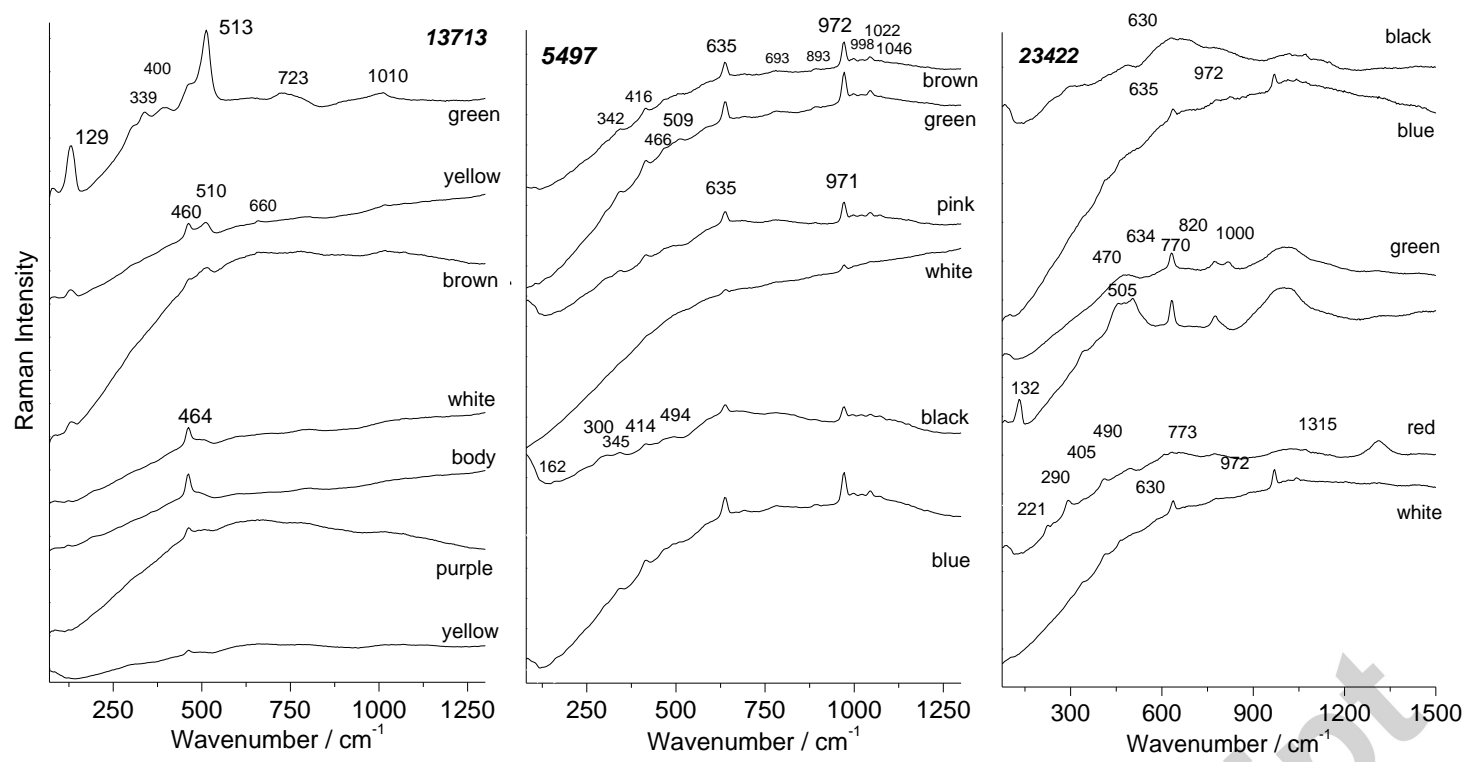

Fig. 6: Representative Raman spectra collected on body, white and coloured glaze. Top spectra are shown as collected. 

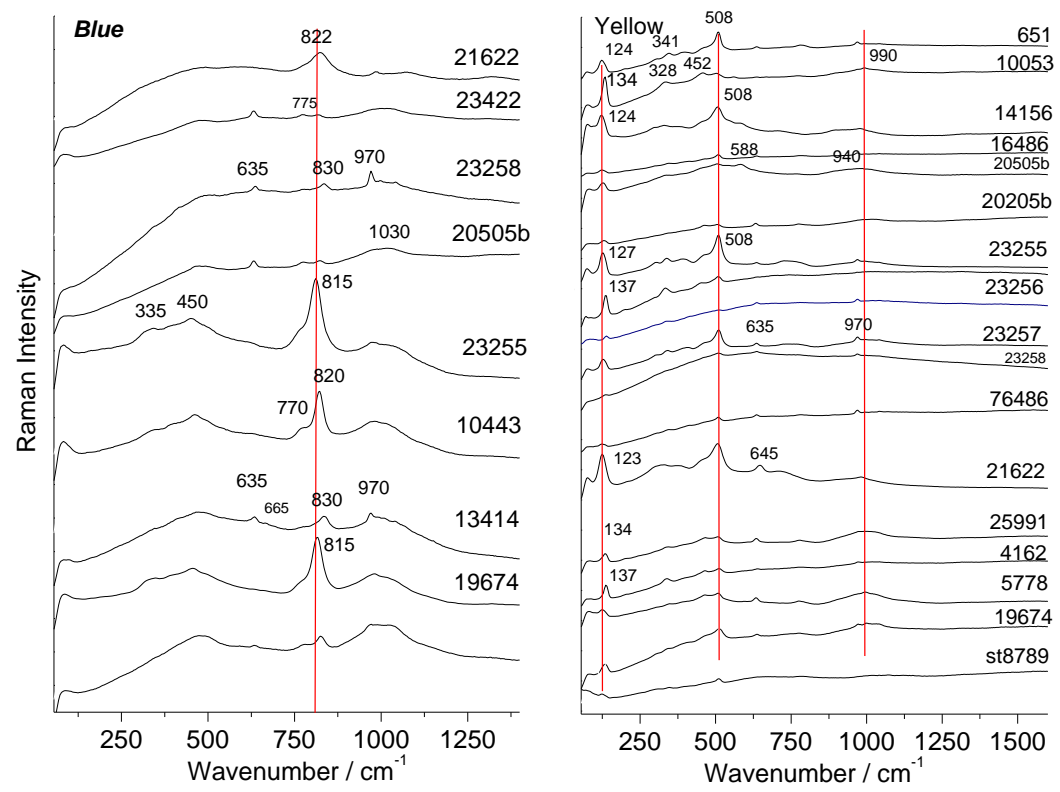

Fig. 7: Representative Raman recorded for blue and yellow décor.

\section{TABLE CAPTIONS}

Table 1: Studied objects listed as "Sceaux faience". Date of production is expected from the stylistic analysis (MNC: Musée National de la Céramique reference number).
Date
Factory
Type (assignment)
MNC
Object 
1753-55

$1750-60$

$1770-80$
Tin oxide glazed faience

Tin oxide glazed faience

Faience fine

Faience fine

Faience fine 20505b plate

$19184 \quad$ pitcher

4162 plate

19674 display plate

25991

tureen stopper

Table 2: Studied objects listed as "porcelain". Date and place of production are expected from the stylistic analysis.

Date Factory Type (assignment) MNC Object

$1754 \quad$ ㅇ $\quad$ Soft-paste $22748 \quad$ clock support


1765-70 Sceaux

“

“

“

“

$\sim 1770$

1774

1775

“
23255 ewer

23256 sugar pot

23257 plate

23258 plate

21622 pot-pourri

13414 pot shadow

13713 pot stopper

10443 sugar pot 
$\sim 1775$

1772-85

$18^{\text {th }} \mathrm{c}$.

$18^{\text {th }}$ c. ?

$18^{\text {th }}$ c. ? Sceaux or Paris?

$18^{\text {th }} \mathrm{c}$. Mennecy

$18^{\text {th }}$ c. ? Mennecy?

$18^{\text {th }}$ c. ? Chantilly or Vincennes?
9096 ewer

5497 mustard pot

26234 figurine

23422 plate

9120 tureen

10053 figurine

St8789 figurine

16486 coffee pot 

$18^{\text {th }} \mathrm{c} . \quad$ ?
“
651 figurine

$18^{\text {th }}$ c. ? ?

$?$

879-7 milk pot

$18^{\text {th }}$ c. ? ?

?

76486 pot stopper

$$
18^{\text {th }} \text { c.? Vinovo? }
$$

?

14156 cream pot

Table 3: Phases identified in the body and in colourless/white glazes of analyzed objects. Dates of production are expected from the stylistic analysis. Assignments in contradiction with visual curator assignment are underlined.

\begin{tabular}{|c|c|c|c|c|c|c|c|c|}
\hline Code & Object & Date & Body ph & ises & & Glaze & & Assignment \\
\hline & $V$ & & Wollastonite & Quartz & Wollastonite & Cassiterite & Quartz & \\
\hline 5778.2 & Plate & 1750 & & & & $\mathrm{X}$ & $\mathrm{x}$ & Faience \\
\hline
\end{tabular}




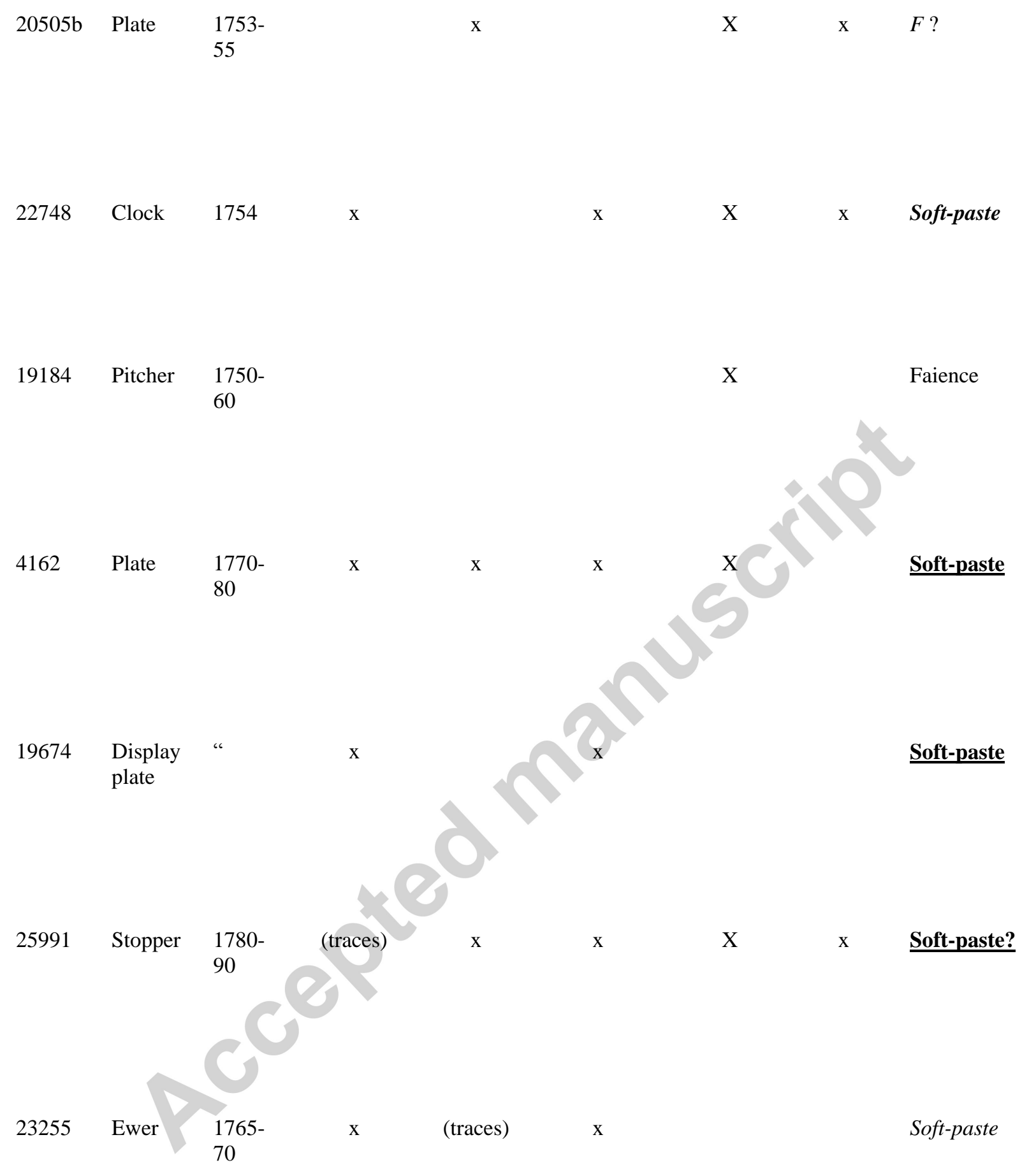




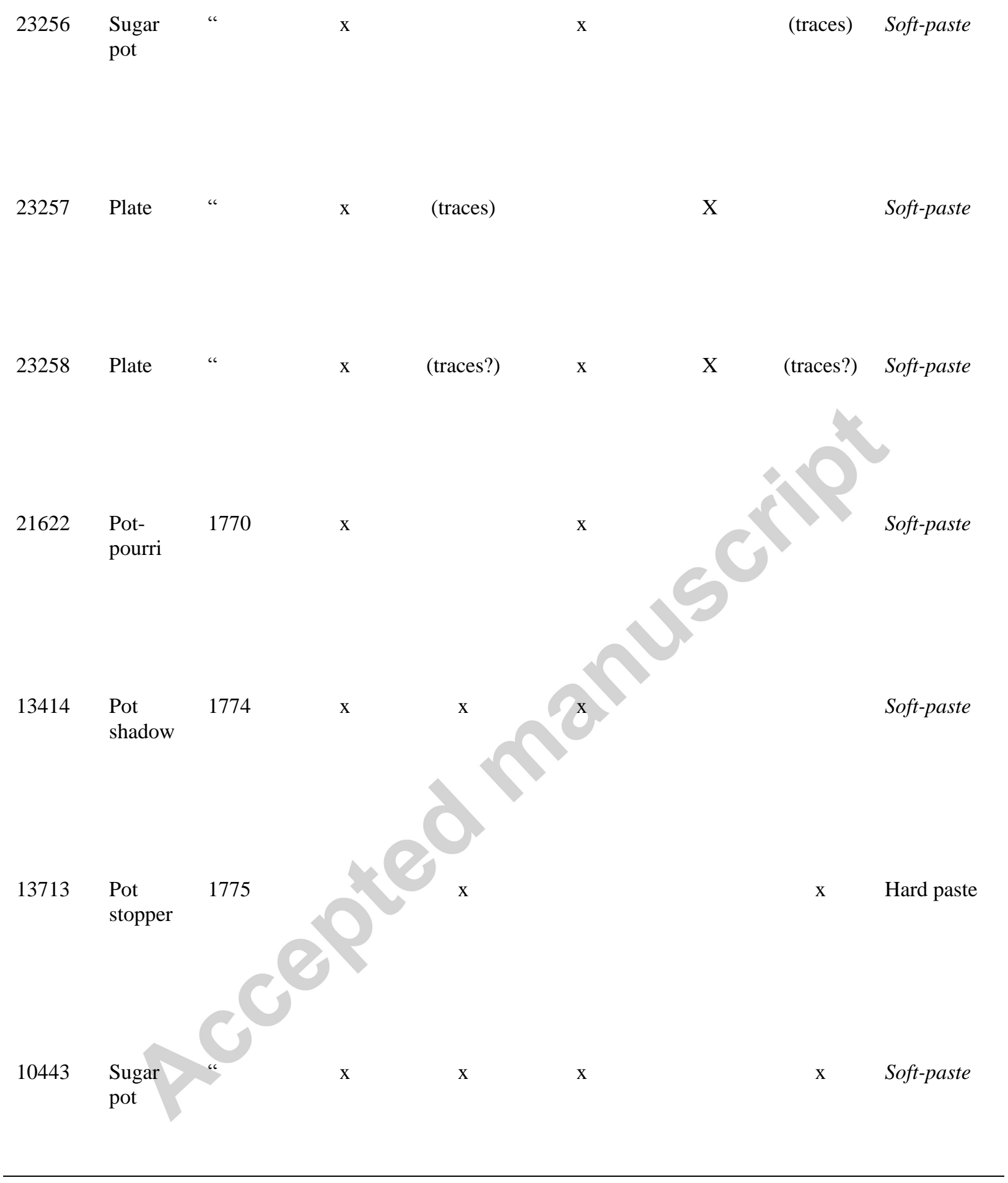


9096 Ewer

$\mathrm{x}$

$\mathrm{x}$

Soft-paste

5497 $\begin{array}{lll}\begin{array}{ll}\text { Mustard } & 1772-\end{array} \quad \text { (traces) } \\ \text { pot } & 85 & \end{array}$ pot

26234 Figurine $18^{\text {th }} \mathrm{c}$

$\mathrm{X}$

$\mathrm{X}$

(traces?) Soft-paste

$23422 \quad$ Plate $18^{\text {th }}$

c.?

9120 Dish “

$\mathrm{x}$

$\mathrm{x}$

$\mathrm{X}$ ?

$\mathrm{X}$

Hard-

paste?

St8789 Figurine $18^{\text {th }}$

c.?

$\mathrm{x}$

$\mathrm{x}$

$\mathrm{x}$

(traces?)

$\mathrm{x}$

Soft-paste

16486 Coffee “

$\mathrm{X} \quad$ (traces)

$\mathrm{x}$
Faience?

Soft-paste 
pot

651 Figurine $18^{\text {th }} \mathrm{c}$.

$\mathrm{x}$

$\mathrm{x}$

Soft-paste

$\begin{array}{lllllll}879.7 & \text { Milk pot } & 18^{\text {th }} & \text { x } & \text { Traces?) } & \text { x } \\ & c . ? & & & \text { x } & \text { Soft-paste }\end{array}$

76486 Pot

stopper

Faience?

14156 Cream “

pot 


\section{ACCEPTED MANUSCRIPT}

\section{Highlights}

- First on-site Raman identification of Sceaux faience and porcelain.

- Differentiation between faience, and soft-paste/hard-paste porcelain.

- faience japponée identification

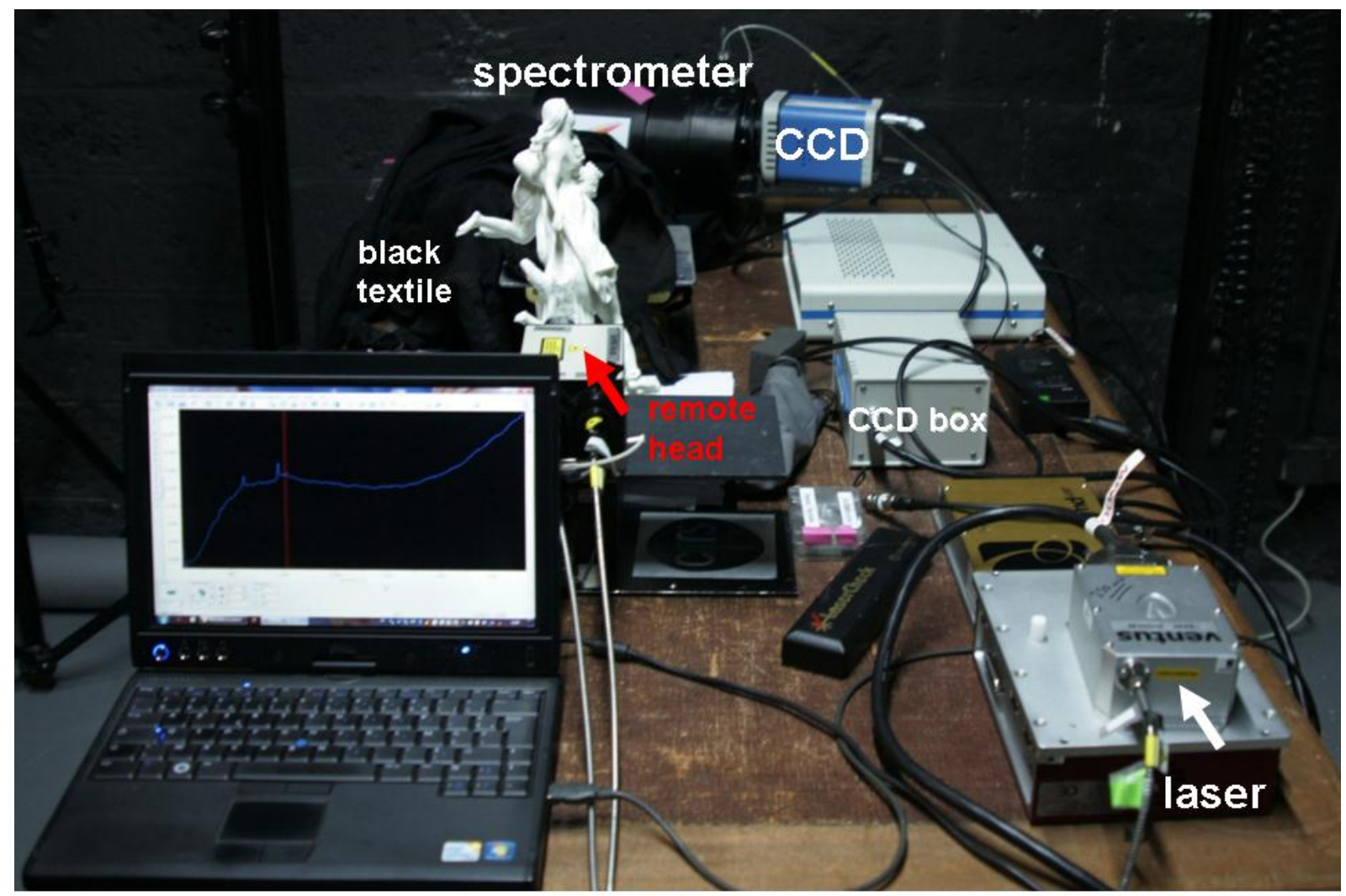




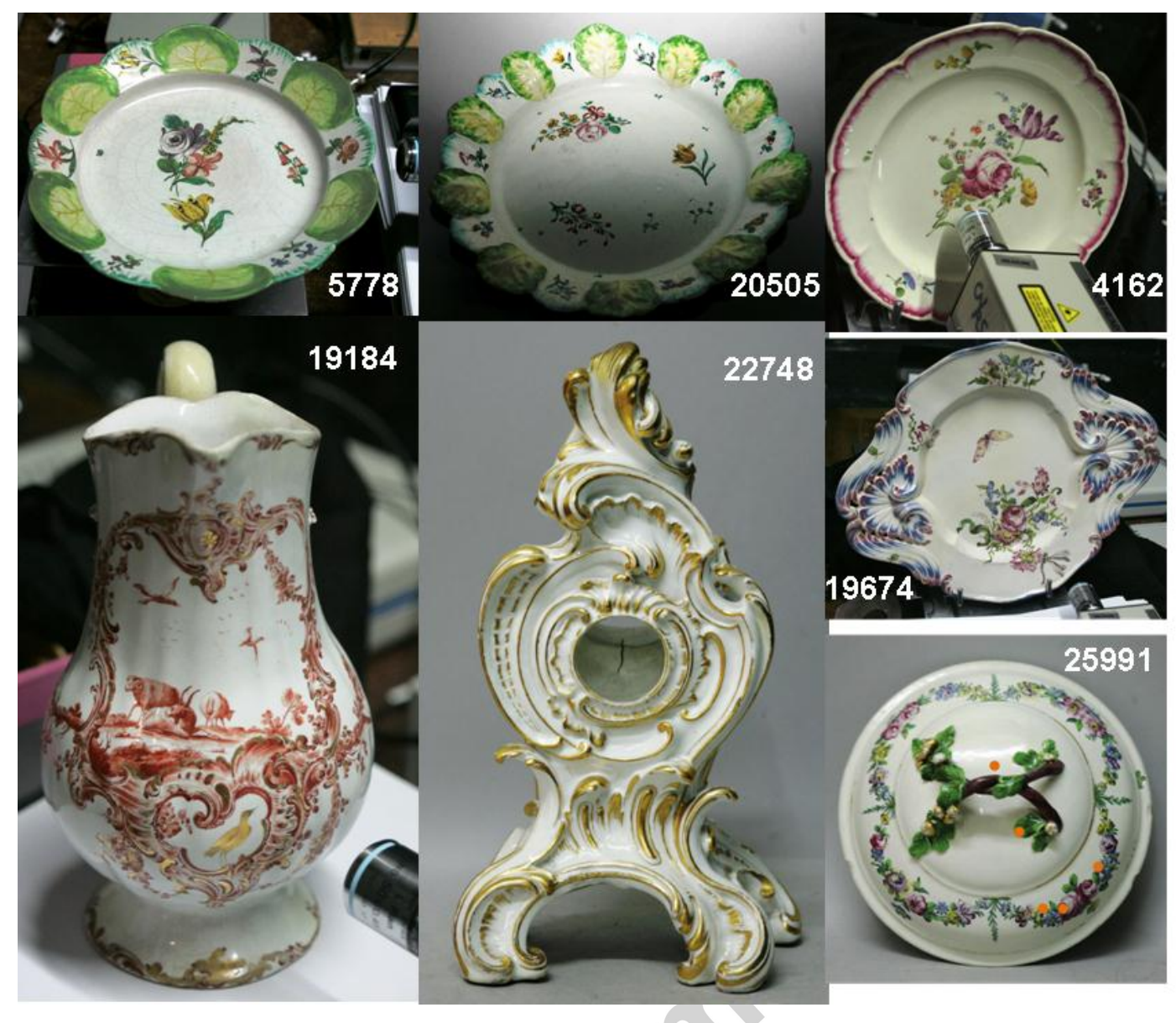




\section{ACCEPTED MANUSCRIPT}

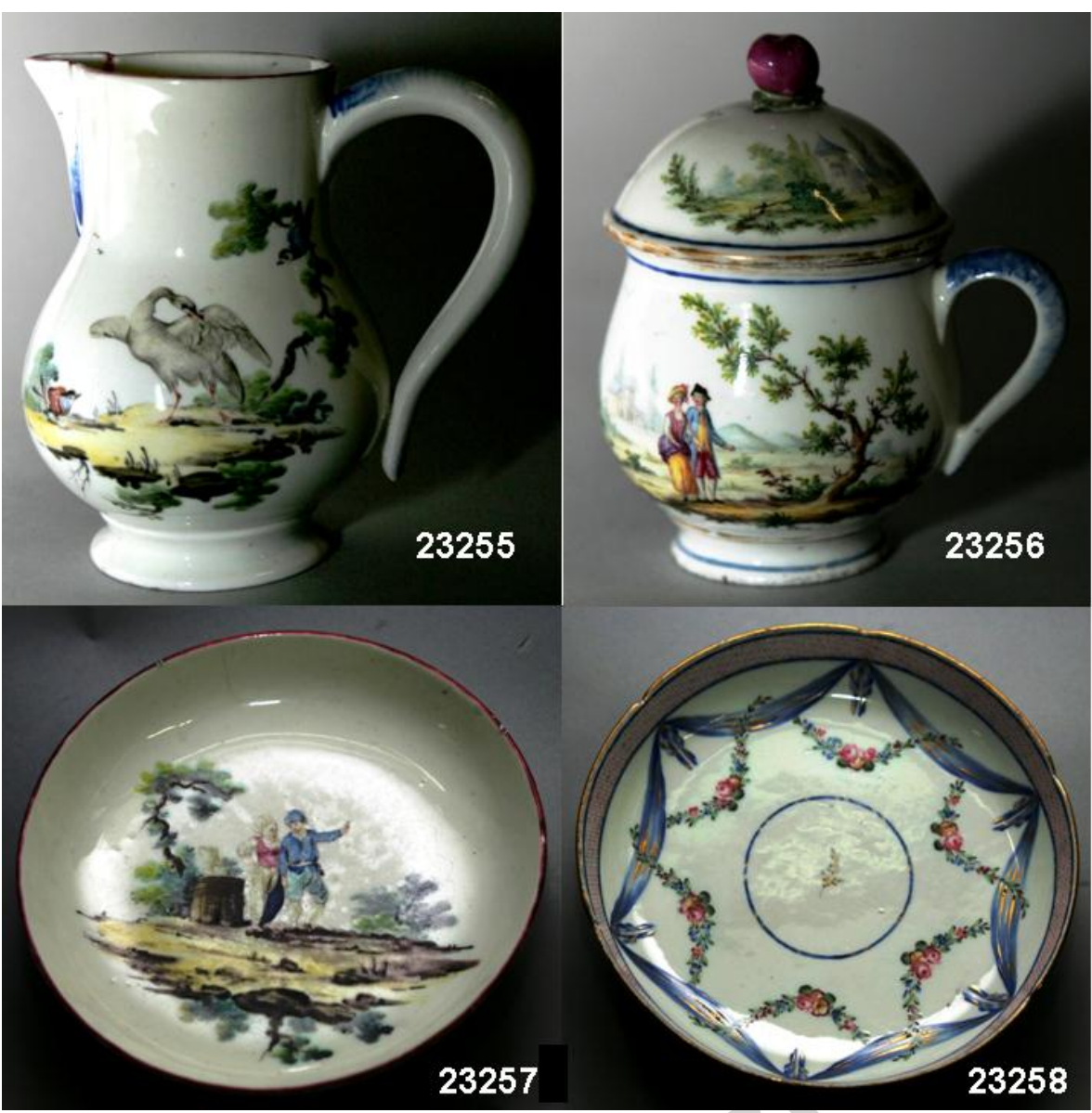




\section{ACCEPTED MANUSCRIPT}

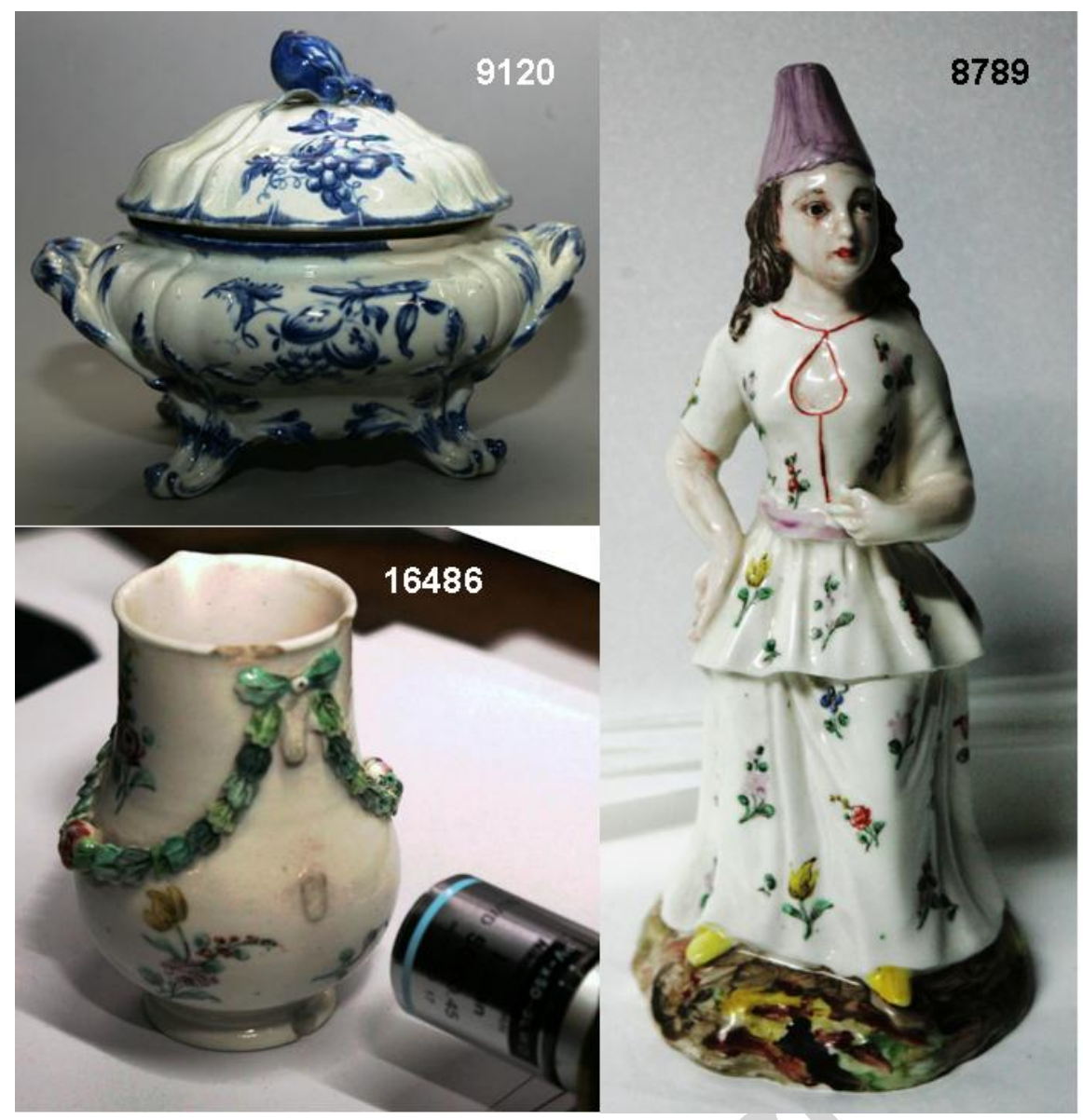




\section{ACCEPTED MANUSCRIPT}

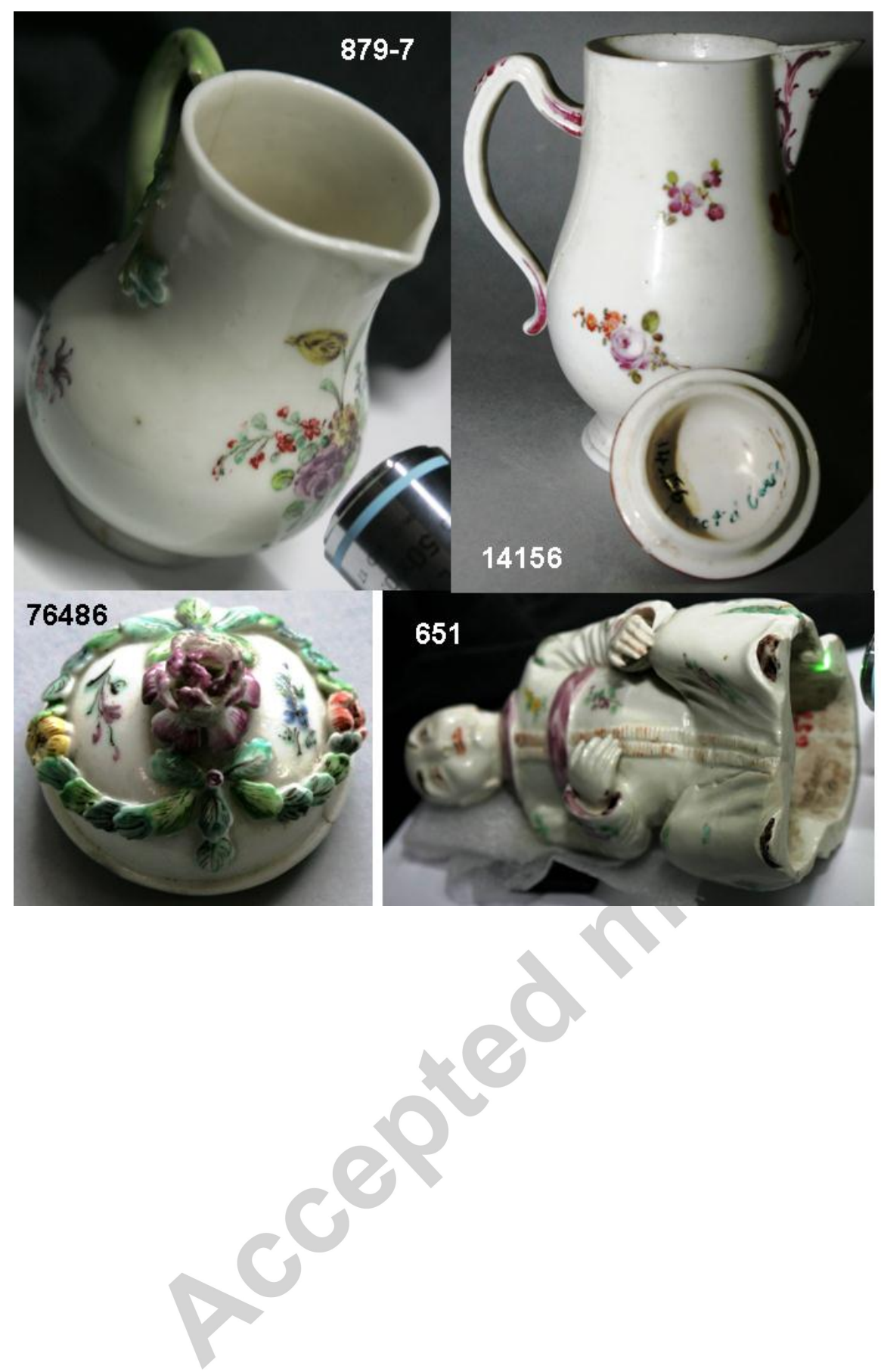




\section{ACCEPTED MANUSCRIPT}

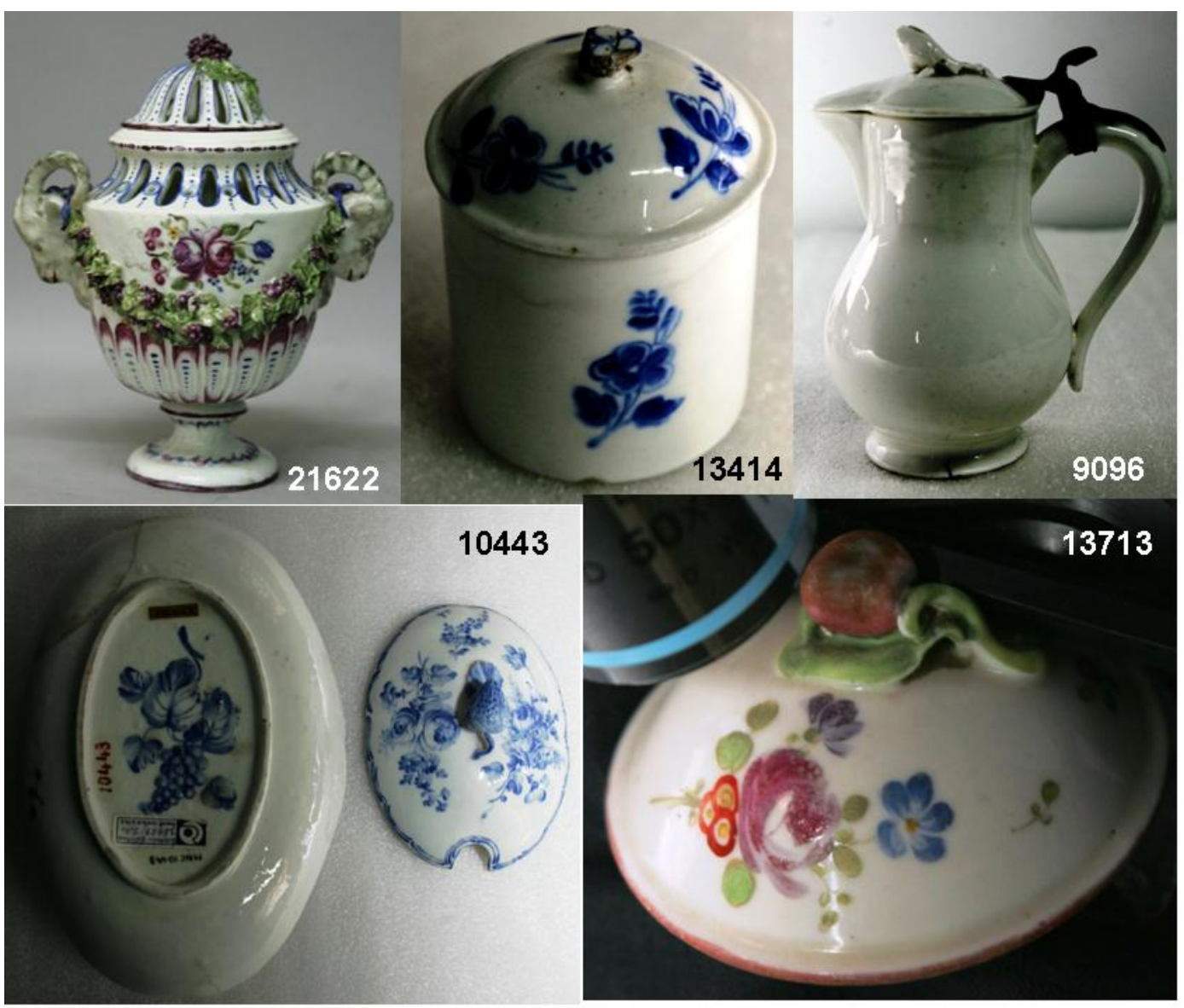




\section{ACCEPTED MANUSCRIPT}
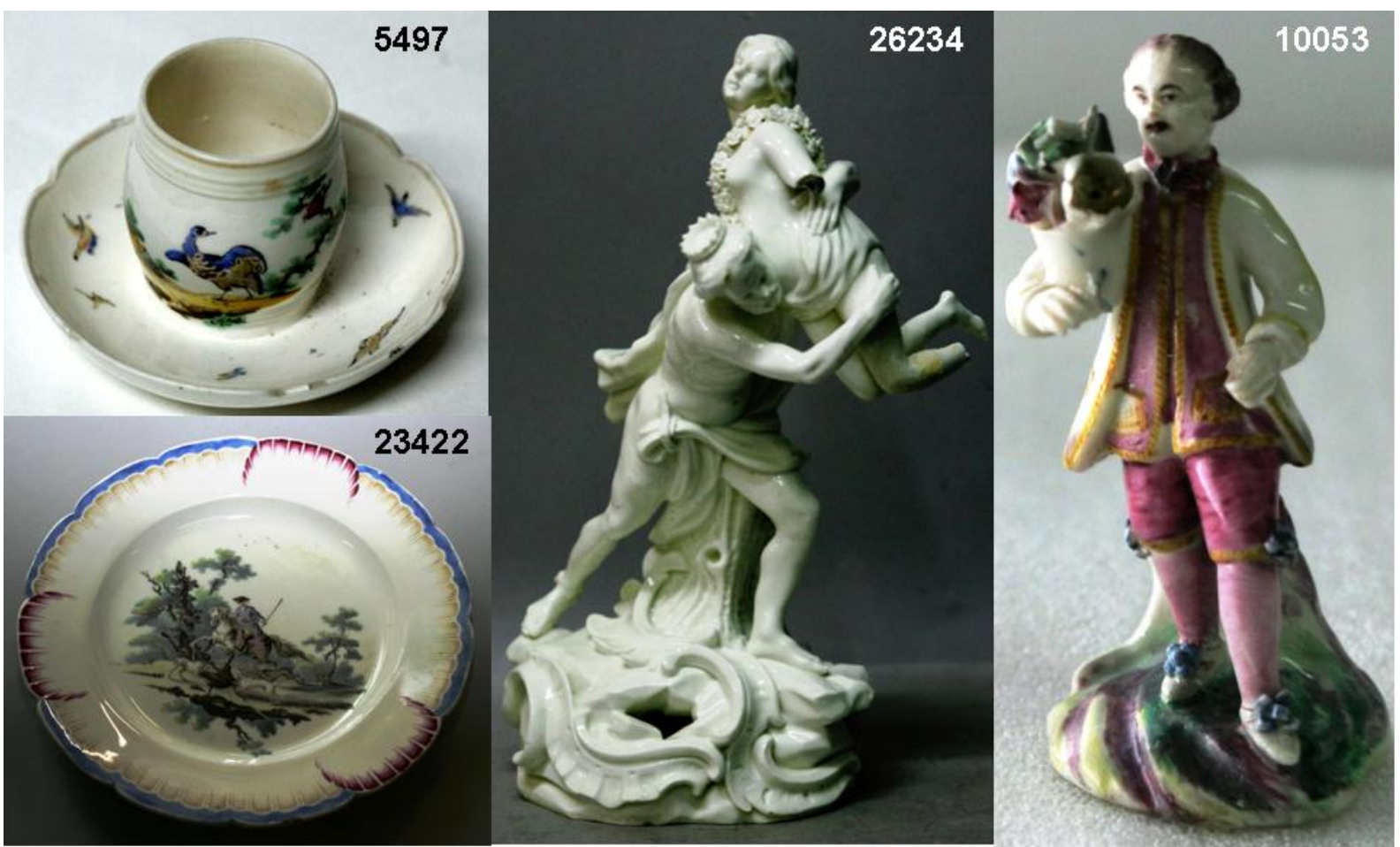